\title{
一方向炭素繊維強化熱可塑性プラスチックスの 高温疲労層間はく離き裂伝ぱ†
}

$$
\begin{aligned}
& \text { 植 松 美 彦* 北 村 隆 行 } \\
& \text { 大 } \\
& \text { 大 谷 隆 - } \text { - }^{* *} \text { 大 塚 裕 之 } \text { 之* }^{* *}
\end{aligned}
$$

\section{Delamination Crack Growth of Unidirectional Carbon Fiber Reinforced} Thermoplastic Polymer under High Temperature Fatigue

by

\author{
Yoshihiko Uematsu*, Takayuki Kitamura**, Ryuichi Ohtani** \\ and Hiroyuki OHTSUKA***
}

Behavior of delamination crack growth in a carbon fiber reinforced plastic (CFRP) was investigated under static creep, two step creep and high temperature fatigue at $473 \mathrm{~K}\left(200^{\circ} \mathrm{C}\right)$ using $\mathrm{DCB}$ specimens. The material was a unidirectional laminate, APC-2, which consists of carbon fibers, AS4, and a thermoplastic polymer, poly-ether-ether-ketone (PEEK). In the static and two step creep tests, the crack propagation rate against time, $d l / d t$, was governed by the energy release rate, $G$, regardless of the stress change. The crack propagation in high temperature fatigue was classified into timedependent and cycle-dependent ones. In the former, the propagation rate against time, $d l / d t$, was correlated well with the energy release rate, $G$, and the relationship coincided with that in static creep $\left(d l / d t=C_{c} G^{m_{c}} ; C_{c}\right.$ and $m_{c}$ are material constants.). In the latter, the rate against load cycles, $d l / d N$, was controlled by the energy release rate range, $\Delta G\left(d l / d N=C_{f} \Delta G^{m_{f}} ; C_{f}\right.$ and $m_{f}$ are material constants.). These imply that the crack grew under the small scale creep and small scale yielding condition, respectively. The condition of transition from the time-dependent crack propagation to the cycle -dependent one was given by a relationship, $C_{\mathrm{c}} \int_{0}^{t_{1}} G^{m_{c}} d t=C_{f} \Delta G^{m_{s}}$, where $t_{1}$ is the cycle period. The fracture surface in the time-dependent fatigue was characterized by the interface cracking between fibers and matrices. On the other hand, the matrix cracking near the fiber dominated in the cycle -dependent fatigue.

Key words : Composite material, CFRP, Delamination, Crack propagation, Creep fatigue, Thermoplastic polymer, Energy release rate

\section{1 . 緒}

言

炭素瀻維強化プラスチックス (CFRP) は，その 比強度の高さによる軽量化効果などのために航空宇宙 分野での使用が期待されており，欧米各国では軍用機 や大型旅客機等の一次構造材としての使用例もある. さらに, 近い将来に実現が期待されている超音速旅客 機や宇宙往還機に扔いては大気圈内での超音速巡航が 想定されるので，空力加熱により機体表面だけでなく その構造材まで高温にさらされる。したがって，高温 条件下でも十分な強度を持つCFRP の開発が重要と なるが, ${ }_{2)}$ FRP の高温強度に関する研究報告はほと んどない．また，CFRP は積層構造を持つため，層 間はく離が主要な破壊モードになると考えられる。.
そこで，本研究では耐熱性があり高温条件下での使 用が有望視される熱可塑性樹脂をマトリックスとする 一方向強化 CFRP 積層板を用いてクリープ拉よび高 温疲労条件下で層間はく離き裂伝ぱ試験を実施し，そ のき裂伝ぱを律速する破壊力学法則について検討した.

\section{2 供試材および試験方法}

供試材は一方向に炭素繊維（AS4）で強化した熱 可塑性樹脂ポリエーテルエーテルケトン（PEEK）

(APC-2，ICI 社製）であり，48層のプリプレグを厚 さ $6 \mathrm{~mm}$ に加圧成形したものを用いた。 その積層構造 および室温における弾性定数と破壊じん性值を Table I に示す．なお，PEEK のガラス転移温度は約 $413 \mathrm{~K}$ $\left(140^{\circ} \mathrm{C}\right)$, 融点は約 $603 \mathrm{~K}\left(330^{\circ} \mathrm{C}\right)$ である.

$†$ 原稿受理 平成 4 年 4 月 14日 Received Feb. 26, 1992

* 学生会員 京都大学大学院 ₹606-01 京都市左京区吉田本町, Graduate Student, Kyoto Univ., Sakyo-ku, Kyoto, 606-01

** 正会 員 京都大学工学部物理工学科 ₹606-01 京都市左京区吉田本町, Dept. of Mech. Eng., Kyoto Univ., Sakyo-ku, Kyoto, 606-01

*** 石川島播磨重工業(株) 厅235 横浜市磯子区新中原町, Ishikawajima Harima Heavy Industry., Isogo-ku, Yokohama, 235 
Table I. Test Material and mechanical properties at room temperature.

\begin{tabular}{|c|c|}
\hline $\begin{array}{c}\text { Prepreg } \\
\text { Carbon fiber } \\
\text { Matrix }\end{array}$ & $\begin{array}{l}\text { ICI APC-2 } \\
\text { Hercules AS4 } \\
\text { ICI PEEK }\end{array}$ \\
\hline Volume fraction of fiber & $62 \%$ \\
\hline Constitution of laminate & $(0)_{48}$ \\
\hline Crystallinity of PEEK & $34 \%$ \\
\hline $\begin{array}{l}\text { Elastic constants } \\
\text { at room temperature }\end{array}$ & $\begin{aligned} E_{1} & =134, E_{2}=8.9 \\
G_{12} & =5.1, \nu_{12}=0.37\end{aligned}$ \\
\hline \multirow{2}{*}{$\begin{array}{lc}\text { Fracture toughness } & K_{\mathrm{IC}}\left(\mathrm{MPa} \cdot \mathrm{m}^{1 / 2}\right) \\
\text { at room temperature } & G_{\mathrm{IC}}(\mathrm{N} / \mathrm{m})\end{array}$} & 4.7 \\
\hline & 1700 \\
\hline
\end{tabular}

試験片は Fig. 1 に示す DCB (Double Cantilever Beam) 試験片であり, 纎維方向とき裂伝ぱ方向が一 致するように切出した. 初期き裂は成形時に厚さ 15 $\mu \mathrm{m}$ のアルミニウム䇴を 2 つ折りにして層間に挿入す ることにより導入し，その長さは $40 \mathrm{~mm} \sim 50 \mathrm{~mm}$ と した，試験片端にはヒンジをネジ止めし，ヒンジの他 方を試験機のプルロッドにピンを介して固定し，負荷 した (Fig. 1).

（i）荷重一定の静クリープ，(ii） 2 段荷重変動クリー プ, (iii) 高温疲労の各試験を実施した. 静クリープ試 験および 2 段荷重変動下のクリープ試験は赤外線加熱 炉を具備した直荷重型クリープ試験機にて実施し，高 温疲労試験には電気・機械サーボ式または電気・油圧 サーボ式疲労試験機を用いた。試験は大気中で行い, 試験温度は $473 \mathrm{~K}\left(200^{\circ} \mathrm{C}\right)$ とした，温度はアルメル ・クロメル熱電対を用いて測定し, 試験部が $\pm 3 \mathrm{~K}$ の

Table II. Test conditions in static and two step creep.

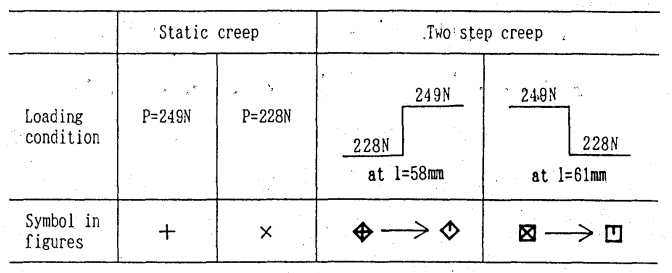

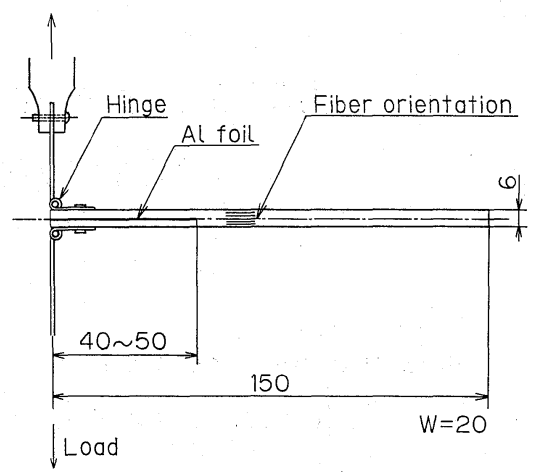

Fig. 1. Double cantilever beam (DCB) specimen (dimensions in $\mathrm{mm}$ ).

範囲に入るよう制御した。 き裂の長さは荷重線からき 裂先端までの距離とし，炉に設けた観察空より測微顕 微鏡で試験中随時測定した。

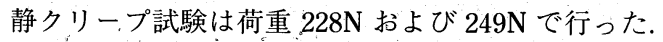
2 段荷重変動クリープ式験では，き裂伝ぱ中に荷重を 増加させたもの (Low-High) と減少させたもの (High-Low) の 2 種類の試験を行った。試験条件の 詳細を Table II に示す. 高温疲労試験は主に最大荷 重 $P_{\max }=228 \mathrm{~N}$, 応行比 $R\left(=P_{\min } / P_{\max }\right)=0.1$ にて行 い, 周期 $1 / \nu$ を $0.5 \mathrm{~s}$ から $4992 \mathrm{~s}$ の範囲で数種類選 んだ. 試験条件を Table III に示す。

また，試験終了後破面に金蒸着を施し，走査型電子 顕微鏡を用いて破面の観察を行った。

\section{3 試験結果および考察}

\section{3 ・1 ・クリープき裂伝ぱにおよぼす応力変動の影響}

Fig. 2 に 2 段荷重変動クリープ試験に扔けるき裂伝 ぱ速度とき裂長さの関係を静タリープ試験の結果と共 に示す。一般に金属材料の2 段荷重変動クリープ試験 では，応力急変直後のき裂伝ぱ速度が同一荷重下の静 クリープのそれより過渡的に加速されたり（LowHigh の場合), 減速される (High-Low の場合)こ とが報告されている。．本試験における CFRP ではこ の様な過渡現象は観察されず, 応力急変直後からき裂
Table III. Test conditions in high temperature fatigue.

\begin{tabular}{c|c|c|c|c|c|c|c|c}
\hline & \\
Laveform
\end{tabular}

伝ぱ速度は対応する荷重の静ク リープのき裂伝ぱ速度とほぼ一 致している，金属材料に㧍ける 過渡現象は主に応力変動直後の 遷移クリープに起因しているの に対して，CFRPの場合には マトリックスのクリープ変形が 高強度の炭素絨維に拘束されて き裂先端近傍のみに限定される 小規模クリープ状態となってい るため, き裂伝ぱは弾性応力場 に支配されて遷移クリープの影 


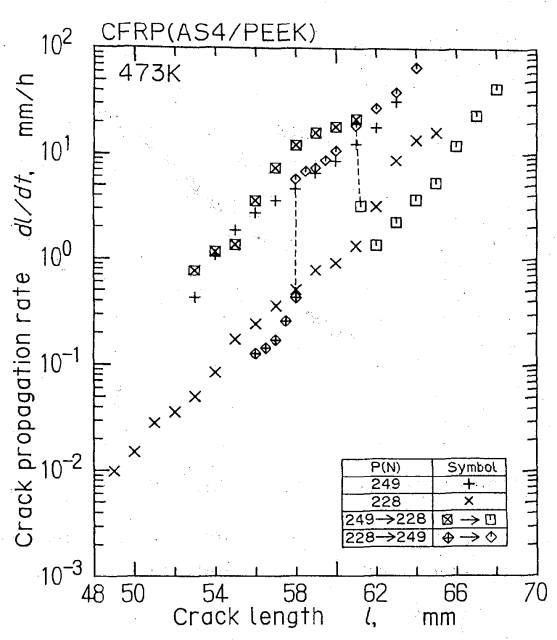

Fig. 2. Relationship between crack propagation rate, $d l / d t$, and crack length, $l$, under static creep and two step creep.

響が現れなかったものと考えられる. Fig. 3 に示すよ うに，2段荷重変動クリープ試験におけるき裂伝ぱ速 度 $d l / d t$ は，静クリープと同様にエネルギ解放率 $G$ と良い対応関係を示す。これは, 上述の小規模クリー プ状態下でのき裂伝ぱを裏付けている.ここで, エネ ルギ解放率 $G$ は次式より求めた.

$$
G=\frac{P^{2}}{2 W} \cdot \frac{d \lambda}{d l}
$$

$P$ は荷重, $W$ は試験片幅, $\lambda$ はコンプライアンスで ある。なお, $473 \mathrm{~K}\left(200^{\circ} \mathrm{C}\right)$ におけるコンプライアン ス $\lambda$ とき裂長さ $l$ の関係は

$$
\lambda^{1 / 3}=0.466+0.0450 l
$$

で表されることが，カミソリで人工的にき裂を導入し たき裂長さの異なる DCB 試験片の負荷-開口変位曲

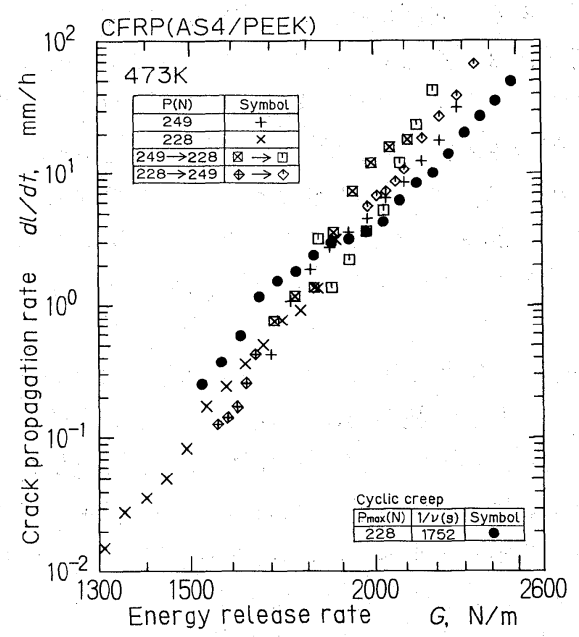

Fig. 3. Relationship between crack propagation rate, $d l / d t$, and elastic energy release rate, G.
線より判明している。 また。, 式(2) と同様の関係が同 材の室温高サイクル疲労き裂についても成立すること がすでに報告されている。

Fig. 3 には荷重保持時間の長い高温疲労試験 (Cyclic creep) の結果も併示している。この場合，き 裂伝ば速度は荷重保持時間に対するものであり，保持 荷重におけるエネルギ解放率との関係をプロットした。 高温疲労試験の結果は静クリープ試験の結果と同様の $d l / d t-G$ 関係を示し, 応力変動の影響は認められな い.これより, 荷重変動がある場合でもき裂はクリー プによって伝ぱし，き裂伝ぱ速度は純時間依存性を示 すことがわかる.

\section{$3 \cdot 2$ 高温疲労き裂伝ぱ}

高温疲労試験の同一 $G_{\max }$ 值 $\left(G_{\max }=1567 \mathrm{~N} / \mathrm{m}\right)$ に おける時間に対するき裂伝ぱ速度 $d l / d t$ と周期 $1 / \nu$ の関係を Fig. 4 に示す. 図の右端に静クリープ試験結

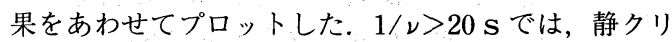

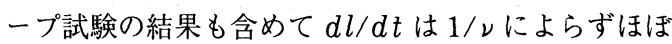
一定であり, マトリックスのクリープに起因する純時 間依存性き裂伝ぱであることが分かる. 一方, $1 / \nu$ $<20 \mathrm{~s}$ では $d l / d t$ は $1 / \nu$ と傾き -1 の逆比例関係に あり, 荷重繰返し数 $N$ に対するき裂伝ぱ速度 $d l / d N$ が一定となっている. これは, 負荷時間によらず 1 サ イクル毎の荷重変動によりき裂伝ぱしたことを示して おり，純繰返し数依存性き裂伝ぱとなっている. すな わち, $1 \% \nu=20 \mathrm{~s}$ を境として高温疲労き裂伝ぱには時 間依存性と繰返し数依存性の 2 種類のき裂伝ぱ形態が 存在することを示している。

一般に，金属材料の高温疲労き裂伝ぱにおいても周 期によって時間依存性と繰返し数依存性のき裂伝ぱが 存在することが知られている. しかし, 金属材料では 両夕イプのき裂伝ぱの間にクリープと疲労の相互作用 領域と呼ばれる中間領域が存在し, その領域ではき裂 伝ぱ速度は時間依存性と繰返し数依存性のき裂伝ぱ速 度の和以上に加速される。：本試験においては時間依存 性から繰返し数依存性への遷移は明瞭であり, 中間周

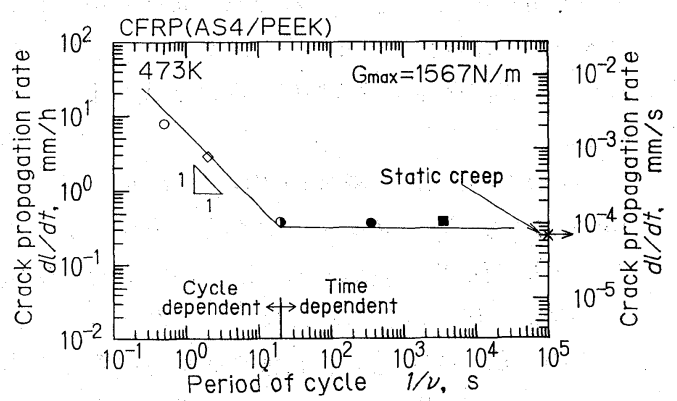

Fig. 4. Relationship between crack propagation rate, $d l / d t$, and period of cycle, $1 / \nu$, in high temperature fatigue. 


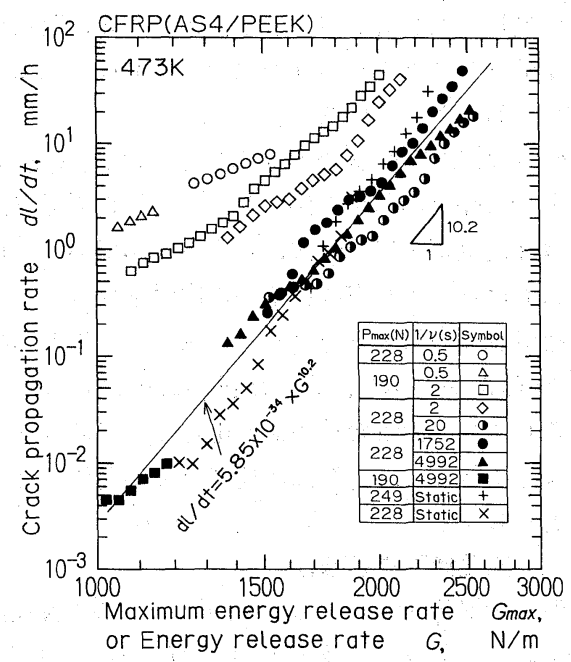

Fig. 5. Relationship between crack propagation rate, $d l / d t$, and elastic energy release rate, $G$, or maximum energy release rate, $G_{\max }$.

期領域の存在は認められなかった。この相違は次のよ うに説明できる．金属材料のクリープ疲労相互作用き 裂伝ぱは，主にクリープ，塑性，弾性の各変形の相互 作用によって生じることが明らかになっている゙.

CFRP ではクリープと塑性変形がき裂先端近傍の局 所にのみ限定されている小規模クリープまたは小規模 降伏状態にあるため，このような恋形の相互作用の影 響は小さく, クリープ疲労相互作用領域は現れなかっ た。

Fig. 5 は本試験における荷重保持時間に対するき裂 伝ぱ速度 $d l / d t$ と保持時のエネルギ解放率 $G$ の関係 である．前節において静クリープでは $d l / d t$ は $G$ と

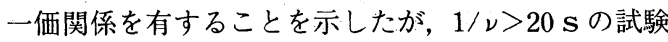
結果（黒印）もほぼ同一の直線上に乗っており，き裂 伝ぱがクリープにより律速されていることがわかる． クリープき裂伝ぱでは $d l / d t$ と $G$ の関係における勾 配が大きいため, $G$ 值が最大荷重保持中の $G_{\max } よ り$ 小さい負荷過程, 除荷過程および最小荷重保持過程で は著しく $d l / d t$ が小さくなるので, 同過程中のクリ ープき裂伝ぱは無視できると考えられる．図中に直線 で示した時間依存性疲労き裂伝ぱ則は次式のようにま とめることができる.

$$
d l / d t[\mathrm{~mm} / \mathrm{h}]=5.85 \times 10^{-34} G^{10.2}[\mathrm{~N} / \mathrm{m}]
$$

Fig. 2 および Fig. 3 の結果を合わせて考慮すると， クリープき裂伝ぱは荷重履歴によらずその時の $G$ 值 のみに律速されていることになる．したがって，式 (3) は Table III 中に示した台形波や矩形波のみならず 一般の波形にも適用できると考えられる．また，時間 依存性き裂伝ぱにおける $d l / d t$ が $G$ で整理できるこ とより, 長周期の高温疲労条件下でも小規模クリープ

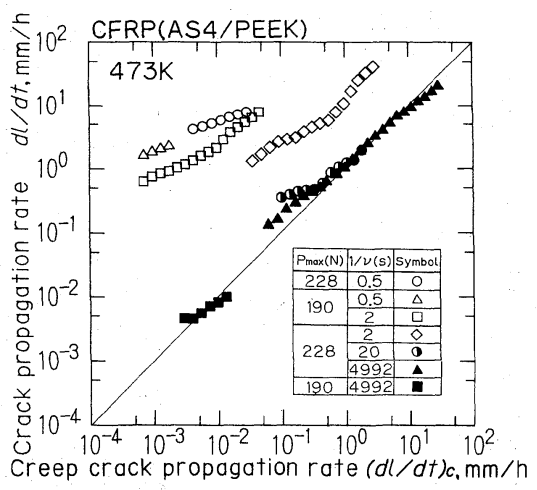

Fig. 6. Comparison between creep crack propagation rate calculated, $(d l / d t)_{c}$ and crack propagation rate, $d l / d t$.

状態が満足されていることがわかる.

一方, $1 / \nu<20 \mathrm{~s}$ の試験結果 (白印) は, $1 / \nu$ が短 くなるにつれて式 (3) の直線関係より高 $d l / d t$ 側には ずれ, $d l / d t$ は $G$ と一価関係を示さない. なお，荷 重波形として正弦波を用いた結果は 1 サイクルの平均 き裂伝ぱ速度 $\nu \frac{d l}{d N}$ を最大エネルギ解放率に対して プロットした.ここで， $1 / \nu<20 \mathrm{~s}$ の矩形波および正 弦波に対するき裂伝ぱ速度がクリープによるものでな いことを示すために，逆にこれらの波形に対しても式 (3)を用いてクリープによるき裂伝ぱ速度 $(d l / d t)_{c}$ を 次式 (4) から計算により求め, 実際に観測されたき裂 伝ぱ速度と比較する。

$$
(d l / d t)_{c}=\frac{1}{t_{1}} \int_{0}^{t_{1}} C_{c} G^{m_{c}} d t
$$

ここで, $t_{1}$ は周期であり, $c_{c}, m_{c}$ は式 (3) の定数 $5.85 \times 10^{-34}$ およよ゙ 10.2 である. Fig. 6 はこの計算結 果と実験により観察された $d l / d t$ を比較して示した ものである. 同図から, $1 / \nu=20 \mathrm{~s}, 4992 \mathrm{~s}$ の結果は 両者がほぼ一致しておりクリープによるき裂伝ぱであ

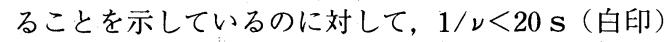
の実際のき裂伝ぱ速度はクリープによるき裂伝ぱ速度 $(d l / d t)_{c}$ よりかなり高速であることがわかる.これ は $1 / \nu<20 \mathrm{~s}$ のき裂伝ぱがクリープによるものでは なく, 時間依存性き裂伝ぱとは異なることを示してい る.

Fig. 7 は繰返し数に対するき裂伝ぱ速度 $d l / d N$ と エネルギ解放率範囲 $\Delta G\left(=G_{\max }-G_{\min }\right)$ の関係である. $1 / \nu<20 \mathrm{~s}$ (白印) の短周期領域（繰返し数依存性領 域）における試験結果はほぼ同一直線上にある。図中 に直線で示した繰返し数依存性の疲労き裂伝ぱ則は次 式のようにまとめることができる.

$$
d l / d N[\mathrm{~mm} / \mathrm{cycle}]=2.29 \times 10^{-20} \Delta G^{5.3}[\mathrm{~N} / \mathrm{m}]
$$

一方, $1 / \nu>20 \mathrm{~s}$ の試験結果（黒印）は, $1 / \nu$ が長く 


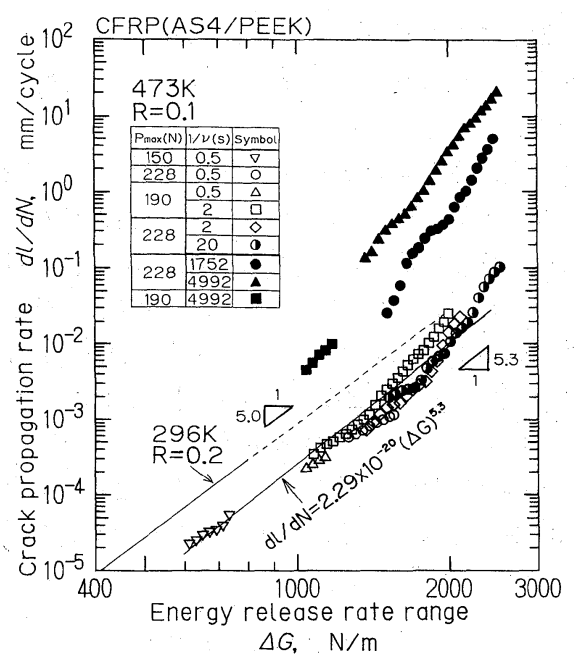

Fig. 7. Relationship between crack propagation rate against load cycle, $d l / d N$, and energy release rate range, $\Delta G$, in room and high temperature fatigue.

なるにつれて式 (4) の直線関係より高 $d l / d N$ 側に移 行しており, $d l / d N$ は $\Delta G$ と一価関係を示さない.

なお, Fig. 7 中には温度 $296 \mathrm{~K}\left(23^{\circ} \mathrm{C}\right)$, 周波数 10 $\mathrm{Hz}$, 応力比 0.2 で行われた同材の室温疲労試験にお ける $d l / d N$ と $\Delta G$ との関係を同時に示した. 高温疲 労試験における $d l / d N$ は室温疲労のそれよりも低く なっている。これは，高温下における PEEK は室温 に比べて延性が増加しており，層間のき裂伝ば抵抗が 増加したためと考えられる。 また，この様にかなりの 高 $\Delta G$ においても $d l / d N$ と $\Delta G$ が直線関係を保つこ と, すなわち, き裂先端において小規模降伏状態が保 たれていることは本材に特徵的な性質である.

以上の結果より，き裂伝ぱが時間依存性の領域では $d l / d t$ と $G$ が, 繰返し数依存性領域では $d l / d N$ と $\Delta G$ が良好な対応関係を示していることがわかる．ま た，両者の境界となる $1 / \nu=20 \mathrm{~s}$ (半黒印) では, Fig. 5，7いずれにおいても良い対応関係を示してい る.

\section{$3 \cdot 3$ 時間依存性き裂伝ぱと繰返し数依存性き裂伝 ぱの遷移条件}

Fig. 4 に示したように，高温疲労き裂伝ぱは時間依 存性および繰返し数依存性に大別することができ，し かもその間の遷移は明瞭である。したがって, 両者の き裂伝ぱ則である式 (3) および $(5)$ からその遷移条件を 求めることができる.

式(3)より時間依存性疲労き裂伝ぱ則は

$$
\begin{aligned}
& d l / d t=C_{c} G^{m_{c}} \\
& \left(C_{c}, m_{c}\right. \text { : 材料定数) }
\end{aligned}
$$

と表され,また式 (5)より繰返し数依存性疲労き裂伝
ぱ則は

$$
\begin{aligned}
& (d l / d N)_{f}=C_{f} \Delta G^{m_{f}} \\
& \left(C_{f}, m_{f}: \text { 材料定数 }\right)
\end{aligned}
$$

と表される。 1 サイクルの周期を $t_{1}$ とすると式(6)よ ク,クリープによる 1 サイクル中のき裂伝ぱ量 $(d l$ $/ d N)_{c}$ は次式より求められる.

$$
(d l / d N)_{c}=\int_{0}^{t_{1}} C_{c} G^{m_{c}} d t
$$

Fig. 5, 7 の結果は $(d l / d N)_{f}>(d l / d N)_{c}$ の場合には繰 返し数依存性のき裂伝ぱ, $(d l / d N)_{c}>(d l / d N)_{f}$ の場 合には時間依存性のき裂伝ぱとなることを示している. したがって，両者の遷移条件は

$$
(d l / d N)_{f}=(d l / d N)_{c}
$$

によって与えられ，これに式 (7) および(8)を代入する と

$$
C_{\mathrm{c}} \int_{0}^{t_{1}} G^{m_{c}} d t=C_{f} \Delta G^{m_{f}}
$$

となる。本試験の場合には，式 (3)，(5)より

$$
\int_{0}^{t_{1}} G^{10 \cdot 2} d t=3.91 \times \Delta G^{5.3} \times 10^{13}
$$

で与えられる.

\section{$3 \cdot 4$ 破面の様相}

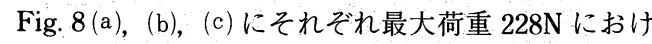
る静クリープ, 周期 $4992 \mathrm{~s}$ （時間依存性領域）およ び $0.5 \mathrm{~s}$ （繰返し数依存性領域）の高温疲労の試験片 破面様相を示す.

静クリープおよび時間依存性高温疲労の破面（Fig. $8(\mathrm{a}) ，(\mathrm{~b}))$ は類似しており, 炭素㵶維が露出した部分 と炭素繊維の脱落した溝が交互に観察され，き裂が繊 維とマトリックスの界面を伝ぱしていることがわかる. また，炭素繊維周囲には大きく変形して引きちぎられ たマトリックスが見られ，両条件とも樹脂のクリープ 変形が先行し，その結果として界面破壊が生じたこと を示している。

一方，繰返し数依存性き裂伝ぱの場合（Fig. $8(\mathrm{c}))$ は, 一部時間依存性き裂伝ぱの破面と同様な繊維とマ トリックスの界面破壊を示す部分が観察されるが，多 くは繊維全体に薄くマトリックスが付着しており, 繊 維近傍のマトリックス破壊となっている. 室温の疲労 破面ではマトリックス破壊が支配的となることが報告 されておりり, 高温でも繰返し数依存性き裂伝ぱの場合 にはこれと類似する傾向が認められる.このように， 時間依存性き裂伝ぱと繰返し数依存性き裂伝ぱとでは 異なった破壊機構でき裂が伝ぱしたことがわかる.

\section{4 結 言}

一方向強化 $\mathrm{CF} / \mathrm{PEEK}$ 積層板を用いてクリープお よび高温疲労下のモード I 層間はく離き裂伝ば試験を 行った. 得られた結果は以下のように要約できる. 


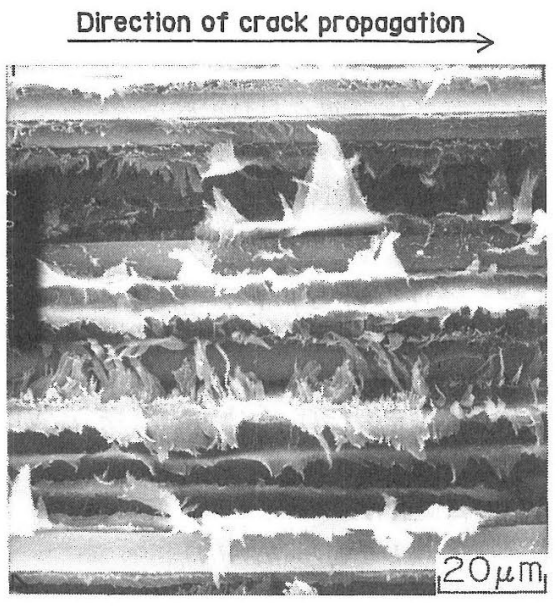

(a) Static creep at load of $228 \mathrm{~N}$.

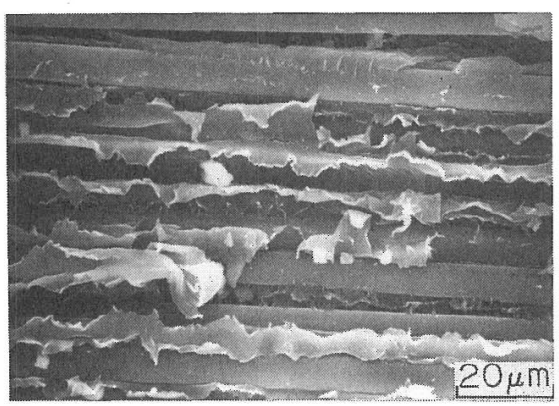

(b) Time-dependent fatigue at the maximum load, $P_{\max }=228 \mathrm{~N}$, and the period of cycle, $1 / \nu$ $=1752 \mathrm{~s}$

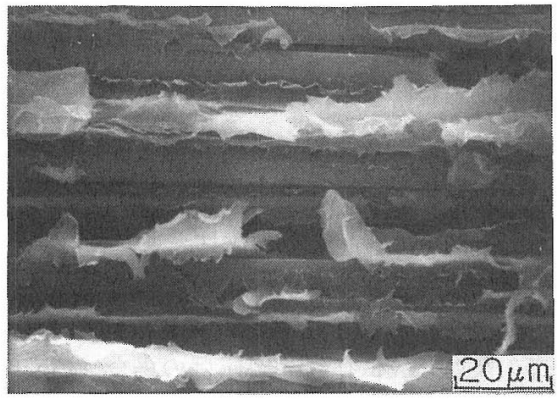

(c) Cycle-dependent fatigue at the maximum load, $P_{\max }=228 \mathrm{~N}$, and the period of cycle, $1 / \nu$ $=0.5 \mathrm{~s}$.

Fig. 8. Fractographs taken by means of scanning electron microscope.

（1） 2 段荷重変動クリープ試験では，き裂伝ぱにお よぼす応力変動の影響は認められない。これはクリー プ変形領域がき裂先端近傍に限定された小規模クリー
プ状態下でき裂が伝ぱするためである。また，き裂伝 ば速度 $d l / d t$ はエネルギ解放率 $G$ によって統一的に 整理できる。

(2) 高温疲労き裂伝ぱは時間依存性のものと繰返し 数依存性のものに大別できる．前者の時間に対するき 裂伝ぱ速度 $d l / d t$ は土ネルギ解放率 $G$ と良い対応関 係 $\left(d l / d t=C_{c} G^{m_{c}}: C_{c}, m_{c}\right.$ は材料定数）を示し, 後者の繰返し数に対するき裂伝ぱ速度 $d l / d N$ はエネ ルギ解放率範囲 $\Delta G$ と良い対応関係 $(d l / d N$ $=C_{f} \Delta G^{m_{f}}: C_{f}, m_{f}$ は材料定数）を示す.

（3）時間依存性き裂伝ぱ則および繰返し数依存性き 裂伝ぱ則より両者の遷移条件は次式で表すことができ る.

$$
\begin{aligned}
& C_{c} \int_{0}^{t_{1}} G^{m_{c}} d t=C_{f} \Delta G^{m_{f}} \\
& \left(Z_{1}: 1\right. \text { サイクルの周期) }
\end{aligned}
$$

（4）破面観察結果より，時間依存性き裂伝ぱの場合 にはき裂は繊維とマトリックスの界面を伝ぱし，繰返 し数依存性き裂妘ぱの場合には主に界面近傍のマト リックス破壊となっていることが判明した。

本研究は, 平成 2,3 年度文部省科学研究費補助金 一般研究 (B) (02452094) の補助を得て実施した。

(平成 4 年 3 月 18 日 日本材料学会第21回 FRP シンポジウムにて講 演)

\section{参考 文 献}

1 ）上田昭夫，航空宇宙機器を支える $\mathrm{ACM}$ ，日経マテリア ル, No.71, p. 170 (1989).

2) N. G. Newaz and S. Mall, J. Composite Materials, 23, 133 (1989).

3 ) 影山和郎，材料，39，235 (1990).

4) M. Hojo, C.-G. Gustafson, K. Tanaka and R. Hayashi, Proc. First Swedish-Japanese Seminar on Composite Materials, p. 52 (1987).

5 ) 大谷隆一, 北村隆行, 平 修二, 日本機悈学会講演諭文 集, 780, 135 (1978).

6 ) 大谷隆一, 北村隆行, 森田宏, 山田雅也, 北條正樹, 日本機械学会論文集, A-57, 556 (1991).

7 ) 北條正樹, 田中啓介, C.-G. Gustafson, P.-A. Cradin, 勋持 潔, 日本機械学会論文集，A-56，1327 (1990).

8 ) S. Taira, R. Ohtani and T. Komatsu, Trans. ASME, J. Engineering Materials and Technology, 101,162 (1979).

9 ) 北村隆行, 大谷隆一, 日本機械学会論文集, A - 52, 1816 (1986). 